5. Jarlier V, Nicolas MH, Fournier G, Philippon A. Extended broad-spectrum $\beta$-lactamases conferring transferable resistance to newer $\beta$-lactam agents in Enterobacteriaceae: hospital prevalence and susceptibility patterns. Rev Infect Dis 1988;10:867-878.

6. Kolár M, Látal T. Antibiotic resistance profile in Klebsiella pneumoniae strains with production of extended spectrum $\beta$-lactamases. Klin Mikrobiol Inf Lék 1997;3:110-114.

7. WHO Collaboration Centre for Drug Statistics Methodology. Anatomical therapeutic chemical (ATC) index (including defined daily doses [DDDs] for plain substances. Oslo, Norway: WHO Collaboration Centre for Drug Statistics Methodology; 1997.

8. Cormican MG, Marshall SA, Jones RN. Detection of extended-spectrum $\beta$-lactamases (ESBL)-producing strains by the Etest ESBL screen. $J$ Clin Microbiol 1996;34:1880-1884.

9. Garau J. $\beta$-lactamases: current situation and clinical importance. Intens Care Med 1994;20:5-9.

10. Brun-Buisson C, Legrand P, Philippon A, Montravers F, Ansquer M, Duval J. Transferable enzymatic resistance to third generation cephalosporins during nosocomial outbreak of multiresistant Klebsiella pneumoniae. Lancet 1987;II:302-306.

11. Knothe H, Shah P, Krcméry V, Antal M, Mitsuhashi S. Transferable resistance to cefotaxime, cefoxitin, cefamandole and cefuroxime in clinical isolates of Klebsiella pneumoniae and Serratia marcescens. Infection 1983;11:315-317.

12. Philippon A, Labia R, Jacoby GA. Extended-spectrum $\beta$-lactamases. Antimicrob Agents Chemother 1989;33:1131-1136.

13. Sanders $C C$, Sanders WE Jr. $\beta$-lactam resistance in gram-negative bac- teria: global trends and clinical impact. Clin Infect Dis 1992;15:824-839. 14. Sirot D, Sirot J, Labia R, Morand A, Courvalin P, Darfeuille-Michaud A, et al. Transferable resistance to third-generation cephalosporins in clinical isolates of Klebsiella pneumoniae: identification of CTX-1, a novel $\beta$ lactamase. I Antimicrob Chemother 1987;20:323-334.

15. Thabaut A, Acar J, Allouch P, Arlet G, Berardi-Grassias L, BergogneBerezin E, et al. Fréquence et distribution des betalactamases chez 1792 souches Klebsiella pneumoniae isolées en France entre 1985 at 1988. Pathol Biol (Paris) 1990;38:459-463.

16. Livermore DM. $\beta$-lactamases in laboratory and clinical resistance. $C l i n$ Microbiol Rev 1995;8:557-584.

17. Medeiros AA. Evolution and dissemination of $\beta$-lactamases accelerated by generations of $\beta$-lactam antibiotics. Clin Infect Dis 1997;24:S19\$45.

18. Richmond MH, Sykes RB. The $\beta$-lactamases of gramnegative bacteria and their possible physiological role. Adv Microb Physiol 1973;9:31-88.

19. Ballow CH, Schentag JJ. Trends in antibiotic utilization and bacterial resistance. Report of the National Nosocomial Resistance Surveillance Group. Diagn Microbiol Infect Dis 1992;15:37S-42S.

20. Kolár M, Látal T. Implementation of the antibiotic policy in the Olomouc region-practical experience of the Center for Antibiotics at FH (Faculty Hospital) in Olomouc [in Czech]. Klin Mikrobiol Inf Lék 1996;7:162-165.

21. Jones RN. The emergent needs for basic research, education, and surveillance of antimicrobial resistance. Problems facing the report from the American Society for Microbiology Task Force on antibiotic resistance. Diagn Microbiol Infect Dis 1996;25:153-161.

\title{
Low Risk of Infection From Common Communion Cup
}

\section{Gina Pugliese, RN, MS Martin S. Favero, PhD}

In response to a controversy surrounding the risk of infectious disease transmission from a communion cup, the CDC recently stated that a theoretical risk exists but is so small as to be undetectable. Experimental studies have shown that bacteria and viruses can contaminate a common communion cup and survive despite the alcohol content of the wine. Thus, any ill person or asymptomatic carrier drinking from the cup potentially could expose other members of the congregation to pathogens present in the saliva. However, a recent study of 681 persons found that people who receive communion as often as daily are not at higher risk of infection compared with persons who do not receive communion or persons who do not attend church services at all.

In summary, the CDC stated that the risk for infectious disease transmission by a common communion cup is very low, and appropriate safeguards (ie, wiping the interior and exterior rim between communicants, use of care to rotate the cloth during use, and use of a clean cloth for each service) would further diminish this risk. In addition, churches may wish to consider advising their congregations that sharing the communion cup is discouraged if a person has an active respiratory infection (ie, cold or flu) or moist or open sores on their lips (eg, herpes).

FROM: Manangan LP, Sehulster LM, Chiarello- L, Simonds D, Jarvis WR. Risk of infectious disease transmission from a common communion cup. Am J Infect Control 1998;26:538539. 